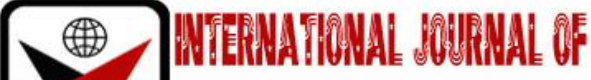

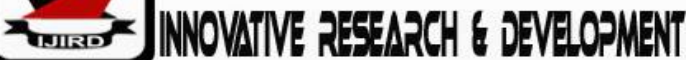

ISSN $2278-0211$ (Online)

\section{Conceptualizing Farm Product Immaturity in the Mfantse Dialect of Akan, Ghana}

Patrick Nana Wonkyi
Lecturer, Department of Akan-Nzema Education,
University of Education, Winneba, Ghana
Lawrence Bosiwah
Senior Lecturer Department of Ghanaian Languages and Linguistics,
University of Cape Coast, Ghana

\begin{abstract}
:
Within the framework of Conceptual Metaphor Theory by Lakoff and Johnson (1980), the present paper discusses the expressions in the Mfantse dialect of Akan, which communicate the state of immaturity in farm products, more precisely farm product + adjectives forms which communicate immaturity (e.g. mango ebun'green mango', Bayerafor 'tender/soft yam' etc.). This study uses a qualitative research approach. The analysis is based on a data collected from six (6) farmers purposively sampled from GomoaAsebu, Ajumako and MfantseNyankomase in the Central Region of Ghana. Data collection tool was a semi-structured interview. We establish that the absence or presence of a given trait of a given farm product determines its state. Thus, the Mfantse conceptualization of immaturity in farm products primarily depends on the used adjectival or verbal forms. The results of our discussion may contribute to the further understanding of the factors that contribute to figurative expressions coinage relating to crop farming vocabulary among the Mfantse people.
\end{abstract}

Keywords: Metaphor, conceptualization, immaturity, Mfantse

\section{Introduction}

Metaphors (and metonyms) are employed in the field of business and economics to communicate and explain complex, abstract and coded concepts (e.g. Charteris-Black, 2000; Henderson, 2000; AlejoGonzáles, 2010; Herrera-Soler \& White 2012 Silaški \& Kilyeni, 2014). Similarly, in Akan and other languages of the world, embodiment and verbs of perception serve as productive lexical items for the metaphoric and metonymic derivations of abstract concepts like love, anger, happiness, victory, sadness just to mention a few (Kövecses, 2014, 2006, 1991, 1990, 1986; Agyekum 2018). Thus, in the Akan example, ANGER IS A GROWING WEED metaphor, The Akan understand and talk about anger in terms of a growing weed - it grows. This metaphor is conventional. The more the source domain (the weeds); the more the target domain (the anger) (see Ansah, 2011).

Among the abstract concepts, pertaining to the crop farming domain among the Mfantse people is the concept of immaturity of farm products. The immaturity expressions differ from crop to crop because farm products exhibit many salient features in their immature state. These features may be conceptualized in terms of many different concepts, depending on the semantic content that needs to be conveyed. As evidenced by Akan scholarly research so far, abstract concepts like anger, shame, love, and many others have been conceptualized in terms of other concepts (Ansah, 2011; Agyekum 2018; etc.)

In this paper, we focus on the figurative expressions used to communicate immaturity of farm products in the Mfantse dialect of Akan. We analyze the factors explored to communicate farm product immaturity. Through this means, we contribute to research into the register of crop farming among the Mfantse people.

The study focuses on the broad category of verbal concepts relating to the concept of immaturity in farm products. This approach follows Lakoff and Johnson (1980), Lakoff (1987) and Lakoff and Turner (1989) in construing metaphor as a relationship between conceptual domains. The concepts like growth and colour serve as the triggers on source precepts in communicating the target domain of immaturity.

The rest of the paper is organized as follows; section 2 discusses theoretical issues and literature relating to the topic at hand, section 3 discusses the Akan language, section 4 discusses the methodology and data collection strategies for this study. In section 5, we discuss data collected from the conceptual metaphor perspective. Section 6 is devoted to the findings that were realized from data analysis while conclusions to the discussion in the paper are drawn in section 7. 


\section{Theoretical Issues and Other Literature}

According to Ungerer\& Schmid (1996), Janssen \& Gisela (1999) and Dirven (2005), Cognitive Linguistics is a linguistic approach which analyses language and its relation to other cognitive domains and faculties such as bodily and mental experiences, image-schemas, perception, attention, memory, viewing frames, categorization, abstract thought, emotion, reasoning, inference just to mention a few. The farm product immature terms are analysed for how it communicates mental experiences and perceptions. The terms figuratively relate to cognitive domains of the Mfantse people.

The paper relates to cognitive semantics which is an approach under a broad approach of Cognitive Linguistics. Cognitive semantics relates linguistic expressions to human cognitive experience.

As asserted by Dirven (2005: 23) that,

Cognitive semantics conceives and understand that knowledge of the world is best mediated through language.

Cognitive linguists are of the view that natural language can be adequately explained in terms of its

semantics and function rather than describing linguistic expressions in terms of the formal rule system

that is completely independent of meaning.

In our analyses we strive to understand the farm product immature terms, how they are conceived and used by natives of the Mfantse language denotatively and connotatively. We as well strive to explain the immature terms from its semantics and function which is dependent on meaning.

According to cognitivists such as Lakoff (1987), Newman (1997), Newman (2002) when someone is explicating a given phenomenon in a given language well he/she needs to depend on and be interested, as well as have respect for the perspective of speakers of the given language. Most importantly one needs to understand the experiential reality of the said phenomenon among the natives of the given language. To best explicate the Mfantse farm product immature terms, we depend on the perspective of natives of the Mfantse language. We strive to understand the experiential reality of the immature farm product phenomenon to explicate other abstract domains.

The paper employs the Conceptual Metaphor Theory (CMT) as propounded and exemplified by Lakoff \& Johnson (1980), Lakoff \& Turner (1989), Hampe (2005), Gibbs (2008) and Kövecses (2014). According to them, metaphor is not a matter of language but a matter of thought and abstract ideas. To them, the metaphorical mind seizes upon the world of spatial concrete, well known, physical categories and, use metaphor to 'transfer' these concepts onto less concrete and ever more abstract, less explain, hard to comprehend domains such as emotion, feelings, time, causality, event structure, just to mention a few. In explicating the farm product immature terms, it is noted that the Mfantse people seize upon the spatial concrete, well-known categories and use metaphor as a medium to transfer these concepts onto a less concrete, abstract concept of immaturity.

Semino (2008: 6) states that,

Cognitive metaphor theorists emphasize that target domains typically correspond to areas of experience that are relatively abstract, complex, unfamiliar, subjective or poorly delineated, such as time, emotion, life or death, reincarnation, resurrection, ghosts. In contrast, source domains typically correspond to concrete, simple, familiar, physical, and well-delineated experiences such as motion, bodily phenomena, and physical objects and so on.

The various immature terms are fundamentally grounded in the conceptual thought patterns or pre-conceptual spatial configurations of the Mfantse speakers. The meaning of these terms does not necessarily stay as basic as is suggested but they have conceptual tentacles that suggest various abstract, poorly delineated ideas like immaturity. According to Trask (2008) metaphor is the non-literal use of linguistics form, designed to draw attention to a perceived resemblance ... it is the mental mapping between two domains: a source domain of familiar meanings and a target domain of the new meaning in focus. Metaphors are conceptually grounded in physical and mental experience (see also Agyekum 2013:3; Lakoff 1993:7).

Lakoff \& Johnson (1980:5) state that, "The essence of metaphor is understanding and experiencing one kind of thing in terms of another" (see Agyekum 2013: 3; Semino 2008: 1). How metaphor is used and applied in given contexts arguably one of the highest manifestations of creativity in the languages of the world. Undeniably, meanings of metaphoric mappings and thoughts cannot be drawn only from literal senses of the words in the metaphoric utterance, so we depend and rely on both literal and conceptual meanings to metaphoric utterances in any language well (see Lakoff \& Johnson 1980; Semino 2008; Agyekum 2013). The physical and mental experiences of the Mfantse people is used as a fertile ground to communicate that the abstract concept of the immaturity of farm products. This is done based on the perceived resemblance between the concepts like colour and motion and the concept of immaturity.

\section{The Mfantse Dialect of Akan}

The subject matter of this study is the Akan group, specifically the Mfantse dialect. According to Agyekum (2010), the Akan language is spoken in the southern part of Ghana. Its dialects include Agona, Akuapem, Akwamu, Akyem, Asante, Assin, Bono, Buem, Denkyira, Fante, Kwahu, Twifo and Wasa. Akan is spoken as a native language (L1-first language) in six of the ten regions in Ghana namely, Ashanti, Eastern, Western, Central, and Brong Ahafo Regions. They are sandwiched by the Ewes in the Volta Region of Ghana as claimed by Agyekum (2006).

Abakah (2013), classify the Akan Language into Mfantse and Twi because all non-Mfantse dialects are Twi dialects. Mfantse comprises three main sub-dialects namely, Iguae, Anee, and Boka (Abakah 1998). The Akan predominantly do crop farming and fishing. The Mfantse speakers are mostly found at the coastal belt of Ghana while the Twi speakers are mostly in the hinterlands of Ghana. According to (Abakah 2013:1) "the label, Fante has been in use ever since life began in Ghana, for the reason that non-FanteAkans and non-Akans alike call it Fante". 


\section{Methodology}

This study uses a qualitative research approach. The analysis is based on a data collected from six (6) farmers who were purposively sampled from GomoaAsebu, Ajumako and MfantseNyankomase in the Central Region of Ghana. The semi-structured interview is the main tool that was deployed to collect data. The farmers were asked questions based on the terms they use to communicate to refer to immature producein crop farming. Furthermore, pictures of immature farm products like fruits and actual farm products like tubers and starchy fruits were shown to them to elicit data on how they conceptualize their immaturity. This helped to elicit terms that described the state of farm products. The interview was done in three weeks. This method saved time. The interviews were audio-recorded. Constructs of the conceptual metaphor theory were applied to data collected.

\section{Conceptualizing Farm Product Immaturity}

In this section, we consider the various conceptualizations of the concept of the immaturity of farm products. The conceptualization is dependent on a salient feature exhibited by farm product. The salient feature is then mapped onto a feature of various dynamic and static entities in the environment. The terms to be looked at in this paper are noted in Table (1). They collocate different farm products.

\begin{tabular}{|c|c|}
\hline Terms & Farm Products \\
\hline 1. ebun(be green) 'immature' & Fruits. \\
\hline 2. afor(be sober/tender) 'immature' & Tubers, Starchy fruits \\
\hline 3. nnyinii (NEG-grow-COMPL) 'immature' & All farm products \\
\hline 4. $\quad$ mmpirimii (NEG-hard-COMPL) 'immature' & Starchy fruits \\
\hline 5. $\quad$ mm-ber-ee ${ }^{1}$ (NEG-red-COMPL) 'immature' & Fruits, Cereal \\
\hline 6. $n n-y \varepsilon-\varepsilon$ we (NEG-reach-COMPL chew) 'immature' & Grains, Sugarcane \\
\hline 7. $\quad n n-y \varepsilon-\varepsilon$ odzi (NEG-reach-COMPL eating) 'immature' & Tubers, Fruits \\
\hline
\end{tabular}

Table 1: Immature Farm Product Terms

After crop flowering, comes fruition. The first state of the farm product is the state of immaturity. At the immature stage, the terms used to describe farm products are seen in Table (1). These terms have their basic meanings. They as well have their figurative extensions or a connotation that is grounded in the culture and everyday life activities of the Mfantse people.

We dwell on the folk theory of immaturity when we are turning our attention to the basic concepts of farm product immaturity in the Akan (Mfantse) context. We do not consider and apply any scientific ideas concerning that. This approach agrees with the experiential reality of native speakers of a given language, which is the sole aim of the cognitive linguistic approach.

Explicitly, we consider how the ordinary Mfantse people conceptualize the immaturity of farm products. This relevant kind of reality may help us explicate the linguistic phenomena of conceptualizing farm product immaturely. We deal with how the concepts they perceive communicate immaturity as rooted in their folk or native understanding of the state of immaturity. To the lay Mfantse man, immature farm product is that which is not ready for consumption or ready for other uses. They base solely on the most salient feature of the immature crop in question to communicate its immaturity. Thus, to communicate the state of immaturity in farm products, the products are conceptualized as a living being, colour and objects. The immature farm products exhibit many features: tenderness, bitterness and many others.

\subsection{Immaturity Is Absence of Growth}

The expression eduaba no nnyinii (lit. the fruit has not grown) 'the farm product is immature' from our data is an instance of the farm product as a living being metaphor. This living being metaphor has proven to be one of the most dominant and effective ways of structuring abstract concepts in crop farming and business and economics respectively (see Herrera-Soler \& White 2012; Wonkyi 2016, etc.).

We note that to communicate the immaturity of farm products, the products are personified. Growth is one of the most striking features of all living beings. It is deemed to be absent in the life of the farm products to communicate their immaturity. This specifically brings the IMMATURITY IS ABSENCE OF GROWTH metaphor. This metaphor is ontological and it provides a certain existential status for the target domain (Kövecses, 2006: 128). Personification allows us to "comprehend a wide variety of experiences with nonhuman entities in terms of human motivations, characteristics, and activities" (Lakoff \& Johnson1980: 33). Hence, to communicate the abstract concept of the immaturity of a farm product, farm product (target domain) is given the qualities of a living being (source domain), growth. Thus, this metaphor is easier to comprehend and deal with, since "personification makes use of one of the best source domains we have - ourselves" (Kövecses 2010: 39). Therefore, we can conclude that among the Akan (Mfantse) people, absence of growth is the absence of maturity.

${ }^{1}$ As revealed in (3-5) in Table (1), the unripe term is negated and written in the past perfect negative tense to communicate the immaturity of farm product. We realize that consonants that begin the unripe terms are prefixed with $\boldsymbol{m} / \boldsymbol{n}$. The consonant $/ \boldsymbol{p}, \boldsymbol{b}, \boldsymbol{f} / \mathbf{m a y}$ take $\boldsymbol{m} \boldsymbol{m i n}$ negation; the rest of the consonants may take $\boldsymbol{n n} / \boldsymbol{n}$ inMfantse. The unripe terms having $\boldsymbol{m}$ or $\boldsymbol{n}$ at word-initial take only $\boldsymbol{m o r} \boldsymbol{n}$ respectively. Also, $\boldsymbol{i} / \boldsymbol{e}$ or $\boldsymbol{i i} / \boldsymbol{e} \boldsymbol{e}$ is suffixed to terms depending on the vowel the verb has at word-final to communicate the exact opposite of the mature farm product terms. However, serial verbs in (6-7) are structured differently, it is only the first verb or the head of the verb phrase that gets prefixed. 


\subsection{Immaturity Is Colour}

The function of our visual systems is to extract biologically important information from our environment (Livingstone, 2008). Colours are always part of human life and they always surround us. Colours represent a strong emotional stimulant, which influences the psychical and physical well-being of Mfantse people. In this section, we discuss colour metaphors that communicate the immaturity of farm products.

Agyekum (2003) states that there are two major concepts when it comes to the semantic representation of the basic colour structure among the Akan. The bright colours, which include red and white, and the dull/opaque, which consist of green and blue. Colours have a direct influence on human subconsciousness so they become powerful symbols and added strong emotional sensation. Through colours the Akan communicate their perceptions, thoughts, believes, etc. People are visual beings. The eyes represent their primary sense, which helps them to orient and understand space.

The linguistic form ebun 'green' is used to communicate immaturity in farm products. This establishes the IMMATURITY IS GREEN metaphor. Most farm products are green in their immature stage. To the Akan, green has a strong relationship with nature, fertility and life. It also symbolizes freshness, fertility and growth. Furthermore, anything that is associated with the colour green may need to grow. Thus, the metaphor fruit + adjective, mangoebun (lit. mango green) meaning 'immature mango'. The basic constructs of the concept of green among the Mfantse people serve as a source domain for the explication of immaturity.

The mango in question is fresh or new in a given system and it may have the desire to grow, stretch and reach its full growth. The mango may crave to grow and will be constantly moving forward and avoid stagnation. Fruits that are deemed immature are seen to be fresh, immature and not ready to be eaten or to be used for other purposes. These are the basic perceptions and notions behind the immature farm product. They use these perceptions to explicate the state of a given noun in several contexts as well.

However, data collection revealed that there is the misconception that the green feature of farm products solely represents the state of immaturity. This is a half-truth because the green colour is just one of the numerous features of an immature farm product. Aside from the greenish nature, there is bitterness, hardness and sourness depending on the farm product in question. But, the most dominant trait of most of the farm products in their immature state is the colour green. The product of the majority of crops is the colour green when they are immature. Some of them stay green in their mature state, others change to have colours like yellow, red just to mention but a few. Fruits in the immature state are left to grow and mature before they are plugged.

The perceptions and thoughts the Mfantse people have about the colour green (freshness, room for growth and purity) serve as a source domain in the metaphoric mappings between the concept of green and the concept of immaturity in the target domain. These perceptions and thoughts are grounds for conceptual mappings from other abstract concepts as well.

Furthermore, in conceptualizing the immaturity of farm products, the absence of features that signal maturity is strongly considered. To the Mfantse people, if the feature that communicates maturity is absent on the farm product in question, the farm product is immature. Therefore, the form mmberee (lit. not red) 'absence of redness' is noted. We, therefore, realize the IMMATURITY IS ABSENCE OF REDNESS metaphor. Therefore, expressions like, Mango no mmberee (the mango is not red) which translate that 'the mango is immature' comes to mind. Farm products like fruits, vegetables and cereal have a 'redness' feature berin their mature state. The Akan communicate their immaturity with the absence of the redness feature.

\subsection{Immaturity Is Softness/Tenderness}

Again, to communicate the immaturity of farm product, the Mfantse people conceptualize a farm product in terms of accessible experience by viewing it as an object. When Mfantse people conceptualize farm products in this way, they tap into the experiential reality of the physical (and social) interaction between our bodies and other entities in the environment. Thus, we may, therefore, have a farm product + adjective expression like Bayerafor (lit. the yam soft/tender) 'the yam is immature' and Boredze no mmpirimii (lit. The plantain that is not hard) 'the plantain is not matured'. These examples can be classified under the farm product is an object metaphor. Through this means, the metaphor IMMATURITY IS SOFTNESS is realized.

The farm products have qualities of soft substances. They take up space. They are three-dimensional and they weigh. An ontological metaphor is therefore achieved in this context. Farm products are perceived as an object made of soft substance. The farm products that are deemed fresh, has room for growth, soft thus are not yet mature. They use these known concepts of softness/tenderness as a foundation to communicate and explain the abstract concept of immaturity. Thus, softness/tenderness marks immaturity. The basic constructs of the concept of softness/tenderness among the Mfantse people serve as a source domain for the explication of the target domain of immaturity.

\subsection{Farm Product Which Is Not Ready to Be Ingested, Is Immature}

The word dzimeans 'eat' in a basic sense. In can be used in diverse ways to communicate other abstract concepts (see Bannerman et al 2011:272-277). The eat term collocate the egestion of most kinds of foods. Thus, farm products like yam, cassava, potatoes, cocoyam and the like are eaten. Also, the form $w e^{\prime}$ chew' is the act of crushing by the teeth by repeatedly closing and the opening of the jaws; it is done to food to soften and break it down by the action of saliva to make it easy to swallow. In eating we chew food. So this form we falls under eat word $d z i$. The form $w e^{\prime}$ to chew'is one of the countless Akan egestion verbs and it collocates solid, fibre and bonelike foods. Thus, farm products like sugarcane and maize come to mind. However, there are instances where the form we is used for liquid foods to communicate drinking in excess. 
When farm products are immature, the Akan, specifically the Mfantse people use how they are ingested to communicate their immaturity. Thus, expressions like Eburow no nnyes we (lit. The maize has not reached chewing stage) 'The maize is immature' and Bankye no nnyecodzi (lit. The cassava has not reached eating stage) 'The cassava is immature' are noted. How the farm products are ingested, is used as grounds to trigger the metaphor of Immature Is Farm Product Which Is Not Ready to Be Ingested. This means, how people relate or use the farm product in question serve as grounding for the conception of the metaphor.

\section{Findings}

Among the Mfantse people, many features conceptualize the immaturity of farm product. They include growth, greenness, absence of redness, and softness/tenderness. The readiness for ingestion of farm products also considered in determining the immaturity of farm products. Based on the features considered we find that farm products are conceptualized as living beings and objects. Thus, metaphors like immaturity is growth, immaturity is green, immaturity is absence of redness, immaturity is softness/tenderness and immature is farm product which is not ready to be ingested Are realized. The Mfantse people have varied perception about the features of immature farm products exhibits. They, therefore, use the perceptions they have about the features (source domain) to explicate the concept of immaturity (target domain).

\section{Conclusion}

Our main aim in this paper was to establish how the Mfantse people conceptualize farm product immaturity. We as well set off to categorize and illustrate the cognitive instruments on which these farm products immaturity expressions are based. We conclude that through the use of metaphor, the abstract concept of farm product immaturity is explicated with concepts like growth, colour, softness and egestion traits. This work adds up to Wonkyi\&Bosiwah (2020), which analysed farm produce metaphorically, considering 'overmaturity' in Mfantse dialect of Akan. We believe that our analysis of the conceptualization of farm product immaturitymay contribute to a further understanding of how conceptualizations and meanings are constructed in crop farming among the Mfantse people.

\section{References}

i. Abakah, E. N. (2013). Vowel Replacement Patterns in the Mfantse Dialect of Akan. Journal of Universal Language, 14(2), 7-51.

ii. Abakah, E. N. (1998). On the Question of Standard Fante. Journal of WestAfricaLanguages 27.1, 94-115.

iii. Agyekum, K. (2018). Akan Body Parts Expressions Cognitive Semantics and Pragmatic Approach. Accra: Adwinsa Publications.

iv. Agyekum, K. (2013).The pragmatics of 'MOUTH' metaphors in Akan. Ghana Journal of Linguistics (2), 1-17.

v. Agyekum, K. (2006). The Sociolinguistic of Akan Personal Names. Nordic Journal of African Studies, 15(2), 206235.

vi. $\quad$ Agyekum, K. (2003). Linguistic Relativity in Akan Cultural Terms. Journal of African Roots (1), 54-77.

vii. Ansah, G. (2011). Metaphor and Bilingual Cognition: The Case of Akana andEnglish in Ghana. Lancaster: Lancaster University.

viii. AlejoGonzáles, R. (2010). Where does the money go? An analysis of the container metaphor in economics: the market and the economy. Journal of Pragmatics 42(4), 1137-1150.

ix. Bannerman, Y. J., Krampah, D. E., Athur, K. G., \& Dickson, K. A. (2011). MfantseNkasafuanaKasambirenyiNkyercase (Vols. I, II). Tema: CEFICKS.

x. Charteris-Black, J. (2000). Metaphor and vocabulary teaching in ESP economics. English for Specific Purposes 19(2), 149-165.

xi. $\quad$ Dirven, R. (2005). Major strands in Cognitive Linguistics. In F. J. Peña, \& F. J. Cervel (Ed.), Cognitive Linguistics Internal Dynamics and Interdisciplinary Interaction (pp. 17-68). Berlin-New York: Mouton de Gruyter.

xii. Gibbs, R. W. (2008). The Cambridge handbook of metaphor and thought. Cambridge: Cambridge University Press.

xiii. Hampe, B. (2005). From perception to meaning: Image schemas in cognitive linguistics. Berlin/New York: Mouton de Gruyter.

xiv. Henderson, W. (2000). Metaphor, economics and ESP: some comments. English for Specific Purposes 19, 167173.

xv. Herrera-Soler, H., \& White, M. (2012). Metaphor and mills: figurative language in business and economics.Berlin/Boston: Mouton de Gruyter.

xvi. Janssen, T., \& Gisela, R. (1999). Cognitive Linguistics: Foundations, Scope, and Methodology. In Cognitive Linguistics Research 15. Berlin/New York: Mouton de Gruyter.

xvii. Kövecses, Z. (2014). Conceptualizing emotions. A revised cognitive linguistic perspective. Poznan Studies in Contemporary Linguistics, 50(1), 15-28.

xviii. $\quad$ Kövecses, Z. (2010). Metaphor. A practical introduction (2nd ed.). Oxford: Oxford University Press.

xix. Kövecses, Z. (2006) Language mind and culture. A practical introduction. Oxford. Oxford University Press.

xx. Kövecses, Z. (1991). Happiness: A definitional effort. Metaphor and Symbolic Activity, 6(1), 29-46.

xxi. Kövecses, Z. (1990). Emotion Concepts. Berlin/New York: Springer Verlag.

xxii. Kövecses, Z. (1986). Metaphors of Anger, Pride, and Love. Amsterdam: John Benjamins. 
xxiii. $\quad$ Lakoff, G. 1993.The Contemporary theory of metaphor. In Metaphor and Thought (pp.1-48). California: UC Berkeley.

xxiv. $\quad$ Lakoff, G. (1987). Women, Fire, and Dangerous Things. Chicago: University of Chicago Press.

xxv. Lakoff, G. \& Johnson, M. (1980) Metaphors We Live By. Chicago: University of Chicago Press.

xxvi. Lakoff, G. \& Turner, M. (1989) More Than Cool Reason. Chicago: University of Chicago Press.

xxvii. Livingstone, M. (2008). Vision and Art. The Biology of Seeing. New York: Harry N Abrams.

xxviii. Newman, J. (2002). A cross-linguistics overview of the posture verbs 'sit', 'stand' and 'lie'. In J. Newman, The linguistics of sitting, standing and lying (pp. 1-24). Amsterdam/Philadelphia: John Benjamins Publishing Company.

xxix. Newman, J. (1997). Eating and Drinking as Sources of Metaphor in English. Cuadernos de FilologíaInglesa, VI (2), 213-231.

xxx. Semino, E. (2008). Metaphor in Discourse. Cambridge: Cambridge University Press.

xxxi. Silaški, N., \&Kilyeni, A. (2014). The money is a solid metaphor in economic and business terminology in English. Professional Communication and Translation Studies 7(1-2), 73-80.

xxxii. Trask, R. L. (2008). Language and Linguistics The Key Concepts (Second Edition). (P. Stockwell, Ed.) New York, Oxon: Routledge.

xxxiii. Ungerer, F., \& Schmid, H-J. (1996). An Introduction to Cognitive Linguistics.London/New York: Longman.

xxxiv. Wonkyi, P. N. (2016). Ekuaye mu NkasafuanaNsemfua ho NhwehwemuwsKasaNtseasee Kwan do. (M. Phil Thesis). Winneba: University of Education.

xxxv. Wonkyi, P. N. \&Bosiwah, L. (2020). Conceptualizing Farm Product Overmaturityin the Mfantse Dialect of Akan. Education Journal Volume 3, Issue 4, 2020, Pages 39-45 